\title{
Work-Life Enrichment as an Important Element of Sustainable Human Capital Development
}

\author{
KATARZYNA MiKOEAJCZYK \\ Organisational Behaviour Unit, Institute of Human Capital, \\ Collegium of Business Administration, SGH Warsaw School of Economics
}

\begin{abstract}
The article is the result of the desk research on time spent by Polish people at work and the different kinds of out-of-work activities undertaken by them. The author's deliberations follow the philosophy of balancing employee needs and promoting work-life balance. The paper includes promotion of the idea of the harmonious growth in all areas of an individual's functioning and activity, as well as the satisfaction of his/her physical and psychological needs. The purpose of the study was to analyse the interactions between work and out-of-work activity in the context of the mutual enrichment of work and personal life. As results from the conducted analyses, the practical implementation of the work-life enrichment idea into organizational behaviours could guarantee high quality of life with no harm to the society, environment or economy.
\end{abstract}

Keywords: out-of-work activity, working time, work-life balance, work-life enrichment JEL Classification Codes: I31, J24 


\section{Introduction}

Sustainable human capital development is a complex concept, comprising human activities in many spheres of life, both at the micro- and macro-economic scale. In the literature, sustainable development factors are assigned to three areas: natural environment, economy, and society, in which an important objective is good quality of life for the present and future generations. David Clutterbuck distinguished six 'lifestreams' that are important for most people to different degrees. These are:

1. work (what you do to earn a living);

2. career (development at work, climbing the career ladder);

3. domestic/social (building and maintaining relationships outside work);

4. health (maintaining physical and mental well-being);

5. self-fulfilment (activity outside work aimed at development);

6. community/belonging (social and civic activity outside work and career) (Clutterbuck, 2005, p. 78).

From the point of view of an organisation, maintaining a balance between the above-mentioned employee functioning areas enables full exploitation of their potential. In this context, a very important question is that concerning activities supporting employees in sustaining that balance, so that the solutions adopted are both favourable to employees and profitable for their employers.

The personal and work spheres are two interacting areas of an individual's functioning. The condition for a satisfactory relationship between the two is their balance, being an element of life stability and understood as a specified proportion of time and energy that an individual devotes to each of these spheres, as well as an individual's sense of satisfaction with the fulfilment of their professional, social, and out-of-work roles. Today's changing social and economic realities do not favour maintaining a balance between these two spheres, which is often manifested in their perception as mutually opposing and difficulties in reconciling out-of-work interests with work (Tomaszewska, 2016). The spread of modern information and communications technologies in the work environment causes employees to stay in contact with their employers nearly twenty-four hours a day, seven days a week. More and more frequently, employees are able to work from different places, not necessarily on the company premises, but rather from home, a café or popular co-working spaces, taking advantage of the possibilities of flexible working time. This results in the boundaries between work and personal life becoming more blurred than in the past. 


\section{How much time do Polish people spend at work?}

According to data for the last quarter of 2017, published by Statistics Poland in March 2019, in the document Rynek pracyw 2017 r. (GUS, 2019), the average weekly working time of the respondent group, working both in their main and additional jobs, was 38.9 hours. As can be noticed in Table 1, there is a difference of three hours between the average time worked by women ( 37 hours) and men ( 40.5 hours). However, the data should be complemented by the actual number of hours including additional jobs, part-time jobs, and overtime, which make a considerable difference to the estimated working week of the Poles. The highest percentage of the employed (62.1 per cent) spent from 40 to 49 hours at work in the reference week. 6.1 per cent worked for 50 to 59 hours and 3.4 per cent spent more than 60 hours at work. Taking into account the data from individual employment sectors in the quarter analysed, in the most numerous section, i.e. manufacturing, $3 / 4$ of the employees (78 per cent) worked for 40 hours or more in the reference week, with 6.1 per cent working for 50 hours or more. In construction, in turn -78.8 per cent worked for at least 40 hours, and 21.7 per cent worked for 50 hours or more.

When analysing Eurostat data concerning full-timers in 2018 for EU Member States and candidate states, one can observe that for the EU-28 Member States, the average working time was 41.2 hours per week. The highest average - 48.9 hours - was recorded for Turkey. Poland was ranked number ten, with the average of 41.8 hours per week for full-timers. Denmark ranked lowest, with 38.5 hours per week.

According to other data, presented by the Organisation for Economic Cooperation and Development (OECD, 2019), a Polish citizen worked for an average of 1,792 hours in 2018 and thus, among the countries covered by the survey, Poland ranked tenth, overtaking e.g. the United States (1,786 hours) or Japan (1,680 hours spent at work). Mexico ranked first, with 2,148 hours worked by a citizen in 2018.

The $8^{\text {th }}$ Labour Market Barometer ordered by Work Service S.A. and prepared by Kantar Millward Brown in 2017 showed that the Poles worked for 45 hours a week on average. The longest hours were worked by persons receiving monthly remuneration of more than 3,999 zlotys, as well as persons conducting their own economic activity. Their average weekly working time was slightly more than 50 hours. As it was pointed out by the authors of the report, the average weekly working time increased proportionally to the earnings. The average weekly working time for persons that earned from 3,000 to 3,999 zlotys was 46.6 hours. Individuals whose monthly salary was between 2,000 and 2,999 zlotys worked for an average of 43.8 hours a week. Those earning up to 1,999 zlotys spent 42.2 hours a week at work. According to the report, men worked for over 5.5 hours longer than women. The average number of 
hours worked in a week by persons working part-time was 33.8. Those employed based on a contract of mandate or a contract for specific work worked slightly more - on average 42.7 hours a week (Work Service Report, 2017).

Table 1. The employed by the number of hours actually worked in the main job in the reference week, by sex and by the selected type of the main workplace's activity (NACE sections) in the $4^{\text {th }}$ quarter of 2017

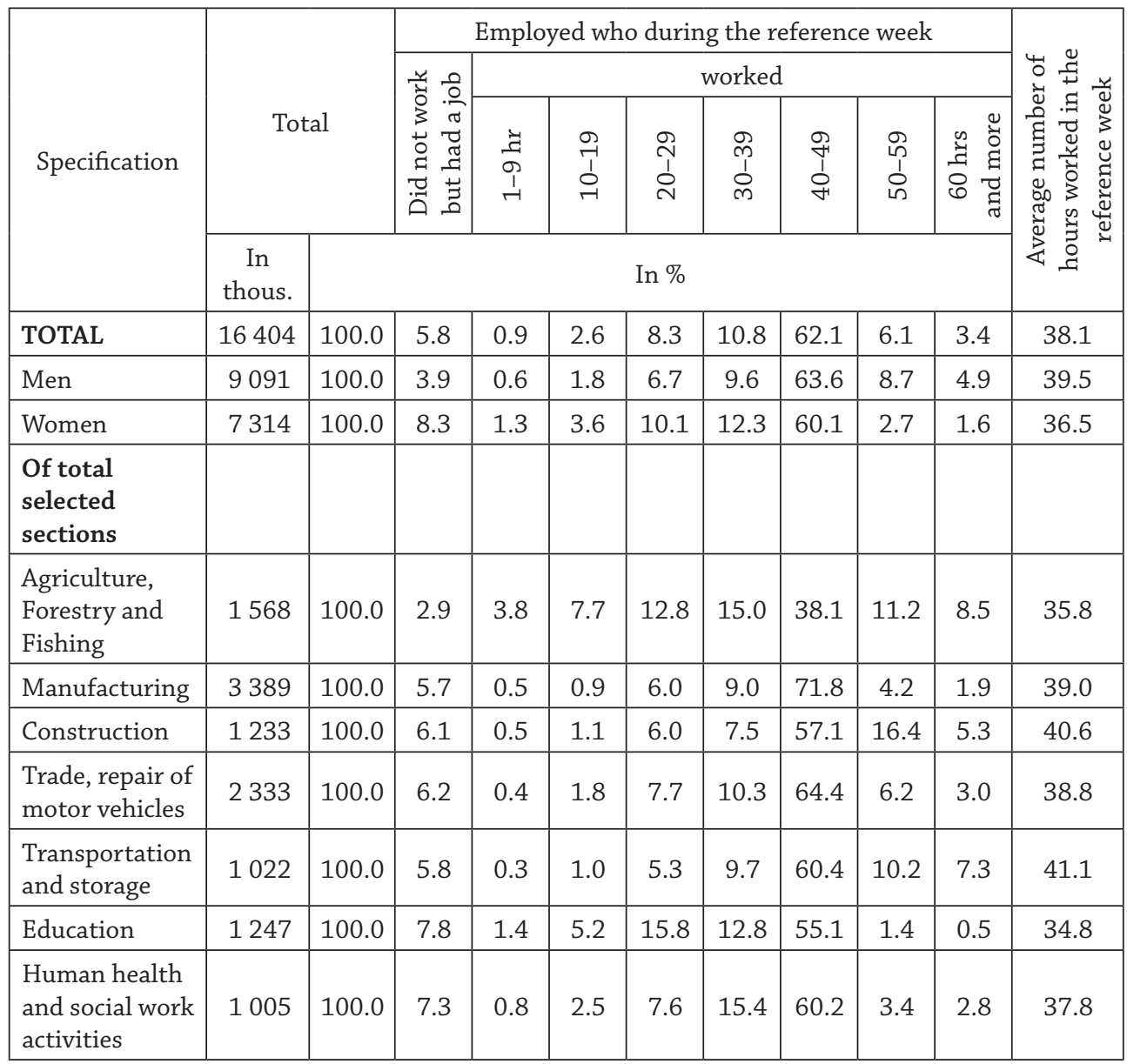

Source: GUS (2019, p. 48). 


\section{Long working time and the well-being of employees}

The statistics quoted above demonstrate that at present, the Poles are among the most overworked nations, despite the fact that already in the late 1960s, long working time was deemed a factor that affects negatively the well-being and physical and mental health of workers (Buell \& Breslow, 1960). Long hours spent at work have long been considered one of the causes of weariness, which can significantly increase the risk of work accidents, nearly to the same degree as lack of appropriate training or failure to use safety measures. In the 1990s, it was found that long working time might be connected with symptoms of depression, anxiety disorders, and insomnia in a group of American soldiers. Similar symptoms of depressed mood and insomnia were also noticed in a group of British accountants (Bliese \& Halverson, 1996).

Long working hours may also affect workers' health indirectly, by increasing the occurrence of other risk factors, such as smoking, alcohol overuse, inadequate diet or lack of physical activity among overworked persons (Tucker \& Rutherford, 2005). Researchers observed that long working time resulted in considerably lower quality of life for overworked persons; in particular, habits related to a healthy lifestyle are abandoned, which can manifest itself in going to bed late, eating improperly or completely abandoning physical activity (Sparks, Cooper, Fried \& Shirom, 1997). A considerable increase in body weight was observed in persons working at computer desks for an average of 45 hours a week for 3 years.

Sometimes long working hours can also have a negative effect on family and social life. A study by Canadian researchers revealed that in families in which both spouses were professionally active, the long working hours of one of them was connected with symptoms of stress, depression, and anxiety in the other spouse. Persons working for long hours experience a work-home conflict, understood as difficulties in fulfilling their domestic duties due to work or professional duties as a result of concern about their home and family (Galambos \& Walters, 1992). According to the World Health Organisation data (WHO, 2017), at present, 320 million people suffer from depression. According to forecasts, by 2030, depression will have ranked second among the most common diseases of civilisation. In Poland, about 1.5 million people currently suffer from depression. It is worth emphasising that depression causes major financial losses, too. In 2018, inspectors of the Supreme Audit Office calculated that the cost of the product lost by society as a result of depression or its treatment, estimated using the human capital method, was approx. 2.6 billion zlotys. Sometimes long hours spent at work have a negative impact on emotions; the body produces too much cortisol (stress hormone), which, in the long term, may affect the immune system of an employee (Maulik, 2017). In the light of the data 
presented above, it is possible to conclude that in the long term, spending a lot of time at work is not a good solution, as an overworked person may be an ineffective and unproductive employee. The lack of balance between work and private life involves a number of negative consequences, which affect both the employee (and their loved ones) and the employer. A shorter working time enables better concentration and thus increases performance. Employees are more involved, to the benefit of the company. According to research, shortening the working time has a positive effect on employees' attitude to their jobs, and additionally, makes employees less prone to conflict situations (Netemeyer, Brashear-Alejandro, \& Boles, 2004).

\section{Work-life balance or work-life enrichment?}

Work-life balance as a time management concept has existed since the 1970s, however, it is only now that it is starting to grow in importance. The essence of work-life balance is described in the literature as "paying attention to maintaining the balance between work life and personal life, which enables an individual to pursue self-realisation in out-of-work life aspects and at the same time maintain an understanding of the multidimensionality of the situation" (Stankiewicz-Mróz, 2008 , p. 314). Work-life balance refers both to the attitude of the employee and the attitude of the employer, which are manifested in various activities aimed at achieving that balance. "The starting point is to perceive your work life and out-of-work life as complementary spheres", and not opposing spheres (Gotowska, 2014, p. 64).

Despite the fact that the Poles, according to the above-mentioned data, are in the top ten of nations spending the most time at work, at the same time, they turn out to be relatively satisfied with their work-life balance. Moreover, working Poles emphasise more frequently than other Europeans that flexible forms of employment, such as flexible working hours and remote work, are becoming more and more common in their workplaces. However, it needs to be stressed that as social and economic changes are taking place, the concept of work-life balance is being redefined and it is increasingly debatable how that balance should be perceived currently.

Over the last ten years it has been observed that the interactions between work and out-of-work life do not merely come down to them being or not being in conflict. Bearing in mind the possibilities of their negative impact on each other, at the same time, attention is paid to their positive interactions. This led to the development of a concept speaking of the mutual enrichment of work and out-of-work life, namely, 'work-life enrichment'. Such enrichment can be understood as "the extent to which experiences in one role improve the quality of life in the other role" (Greenhaus \& Powell, 2006, p. 73). Work-life enrichment is bidirectional: work experiences 
can positively influence the quality of private life and out-of-work experiences can improve the quality of life in the work sphere. For instance, your private life can become a source of positive emotions that will be transposed to your functioning at work. Another form of enrichment is a situation where work shapes an individual's skills, behaviour patterns, attitudes or ways of thinking that make it easier for them to fulfil their family or citizen roles. Thanks to work, an employee can develop a sense of duty or gain self-confidence, and these features enable them to become a better partner, community activist, friend or parent (Chan et al., 2016). Another stage in the development of the concept of work-life balance was the observation that family was not the only sphere of an individual's functioning that could affect their well-being or fulfilment of work duties. Social, cultural, religious, and sports activities, hobbies, leisure, education - these are only some of the important elements of a human life that can remain in balance or in conflict with work.

In a study conducted in the United States concerning the issue described herein, it was analysed what areas of the out-of-work functioning of an individual were most disrupted by work (Henion \& Ryan, 2013). The study covered more than 5 thousand individuals. 70 per cent of the group were married or had a partner and about 44 per cent had more than one child. It was found that three spheres of life were in a particularly serious conflict with work: health, including physical exercise and visits to doctors, family, and leisure (e.g. hobbies, sports, reading books, watching television, travelling). Interestingly, the results were similar both for employees having families and those living on their own. These results can be an argument in favour of the increasingly popular thesis that work-life balance is not limited to harmonious relationships between work and family, but it is a certain state of synergy between the work life and the general out-of-work life of an employee.

Both in Poland and in the entire European Union, a great majority of respondents who are currently employed are satisfied with their work-life balance. The highest percentages of satisfied respondents are recorded for Denmark, Austria, and Finland, while the most dissatisfied nations are those of Greece, Romania, and Spain. In Poland, the groups that are most satisfied with their work-life balance are the youngest respondents - those who are just entering the labour market and starting their careers - and those aged 55 and more who only have to work for a few more years (Flash Eurobarometer 470, 2018). As demonstrated by the results of the 12th Labour Market Barometer, presented in Chart 1, the introduction of a work-life balance programme in the company was the fourth most popular choice among employees (58.2 per cent), right after remuneration solutions, in the list of factors affecting the decision to continue working for a given organisation (Work Service Report, 2019). 


\section{Chart 1. Respondents' answers to the question: what company actions would have a significant influence on your willingness to continue your employment in the present company?}

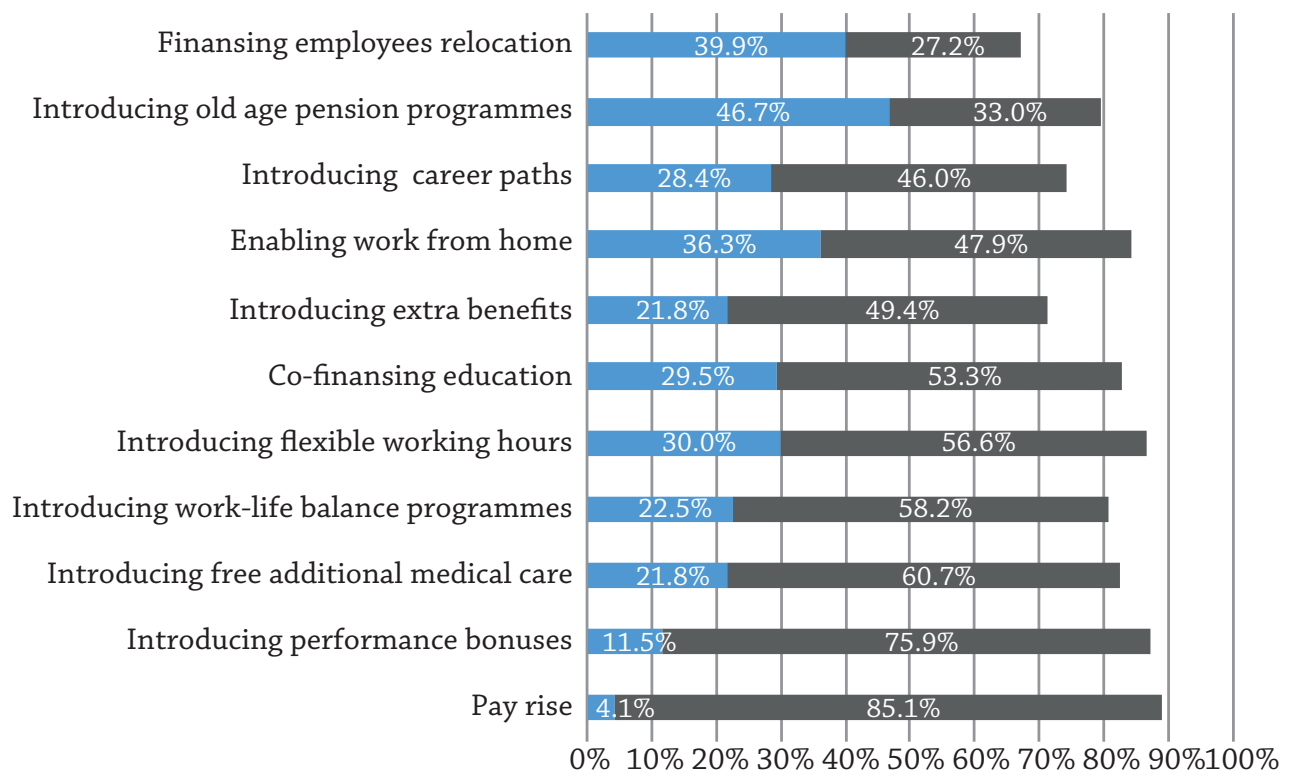

Element last important to employees

Element most important to employees

Source: Work Service Report (2019, p. 16).

Based on the results of a survey carried out by Employer Branding HRK S.A., it can be observed that more and more companies are offering their employees support in pursuing their out-of-work interests and hobbies. Nearly all employers offering work-life balance programmes finance or co-finance the participation of their employees in sports activities. However, one third of the organisations analysed implements a broader range of measures. Exercise facilities and sports fields are being created on company premises, employers are financing the activity of employee groups doing various sports, organising sports competitions, financing the participation of employees in independent sports events (very popular events include races or marathons), organising competitions promoting physical activity, investing in their own sports teams (e.g. football, volleyball or triathlon teams), and taking care of contestants' preparation for sports events, e.g. by providing them with trainers and dietary advice (HRK, 2016). Employees, in turn, identify specific aspects that are important to them, which results in work and private life being mutually complementary and matching each other in different ways, depending on the employee's stage of life. More and more employees believe that work should be an 
important sphere of life and should not be separated by some artificial barrier from other life activities. All spheres of life should naturally interact with one another, with none of them being the dominant one.

\section{How do Polish people pursue self-actualisation out of work?}

A recent study conducted by the Public Opinion Research Center was trying to determine what currently made up the everyday life of Polish people and what types of activities they devoted themselves to out of work. The results of that analysis are presented in Table 2. They indicate that Polish people would like to devote more time to travelling. 43 per cent of the respondents selected this answer when responding to the question: "To what would you devote yourself to a greater degree than presently?". Family life ranked second, with the result of 39 per cent, and enjoying life, i.e. entertainment and other pleasures, ranked third. Only 19 per cent of the respondents declared that they would like to devote more time to work, 17 per cent - to doing sports, and 15 per cent would like to participate more actively in cultural life. The needs to travel, be physically active, and participate in cultural life are mostly declared by persons enjoying the best financial status, having higher education, and living in the largest cities. The desire to travel more is most frequently expressed by younger persons - below the age of 24 , and the willingness to do more sports is declared especially by the respondents aged more than 35 .

Those least educated and the oldest, i.e. farmers and old age pensioners, would like to devote more time to health protection and religious life. 72 per cent of the respondents declared that the most important part of their everyday life was their family, and 53 per cent indicated work. 28 per cent of Poles devote time and energy to health protection and treatment every day.

The findings of the study also indicate that the respondents' sense of dissatisfaction most often comes from those domains to which they already devote relatively more time than others. For instance, the persons who devote themselves to family life on a daily basis would like to have even more time for their families. The respondents working for the benefit of others would like to expand their social activity, and those who prefer enjoying life would like to do that even more often. The report shows that due to the increased wealth of the society and the increasing degree of satisfaction of the basic needs, at present, Polish people are more rarely focused on accumulating wealth and striving for survival than in the past, and they concentrate on family life and their own pleasures more frequently. 
Table 2. Respondents' answers to the question: To what would you devote yourself to a greater degree than presently, if only that was possible?

\begin{tabular}{|c|c|c|c|c|c|c|c|c|c|c|c|c|c|c|c|c|c|c|c|c|}
\hline \multicolumn{21}{|c|}{ To what would you devote yourself to a greater degree than presently, if only that was possible? } \\
\hline $\begin{array}{l}\text { Which of the activities } \\
\text { listed below is currently } \\
\text { dominant in your } \\
\text { everyday life? To which } \\
\text { of these activities do } \\
\text { you devote the most } \\
\text { time and energy? }\end{array}$ & 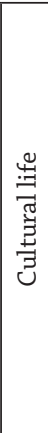 & 竞 & 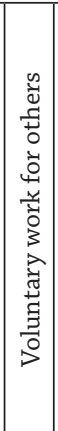 & 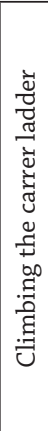 & 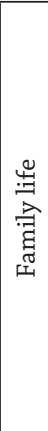 & 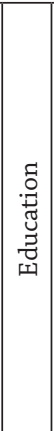 & 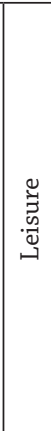 & 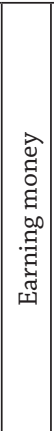 & 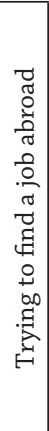 & 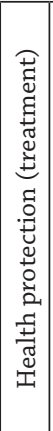 & 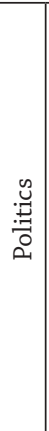 & 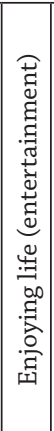 & & 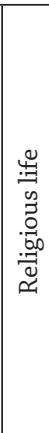 & 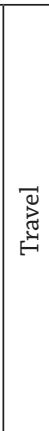 & 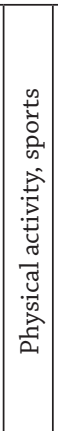 & 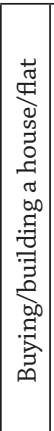 & 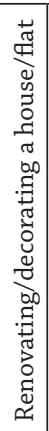 & 苞 & 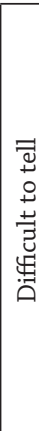 \\
\hline Cultural life & 18 & 18 & 16 & 7 & 30 & 27 & 4 & 5 & 3 & 14 & 4 & 25 & 2 & 1 & 47 & 18 & 3 & 9 & 0 & 3 \\
\hline Work & 18 & 18 & 9 & 5 & 41 & 12 & 3 & 8 & 2 & 12 & 1 & 25 & 1 & 4 & 49 & 19 & 9 & 9 & 2 & 2 \\
\hline $\begin{array}{l}\text { Voluntary work for } \\
\text { others }\end{array}$ & 13 & 19 & 41 & 6 & 50 & 12 & 0 & 6 & 0 & 14 & 8 & 10 & 3 & 11 & 31 & 26 & 3 & 8 & 3 & 1 \\
\hline $\begin{array}{l}\text { Climbing the career } \\
\text { ladder }\end{array}$ & 18 & 13 & 8 & 23 & 19 & 14 & 6 & 28 & 0 & 0 & 0 & 33 & 0 & 0 & 16 & 20 & 19 & 8 & 0 & 10 \\
\hline Family life & 16 & 20 & 10 & 3 & 43 & 9 & 3 & 6 & 1 & 16 & 1 & 21 & 1 & 4 & 47 & 18 & 8 & 10 & 1 & 4 \\
\hline Education & 17 & 20 & 12 & 9 & 32 & 13 & 4 & 10 & 10 & 7 & & 25 & & 1 & 55 & 18 & 21 & 4 & 2 & 1 \\
\hline Leisure & 12 & 26 & 14 & 3 & 15 & 14 & 21 & 13 & 4 & 14 & & 36 & 2 & 0 & 57 & 17 & 4 & 0 & 0 & 0 \\
\hline Earning money & 6 & 21 & 6 & 6 & 37 & 11 & 8 & 16 & 1 & 15 & 2 & 29 & 1 & 3 & 46 & 12 & 13 & 12 & 1 & 1 \\
\hline $\begin{array}{l}\text { Trying to find a job } \\
\text { abroad }\end{array}$ & 14 & 14 & 47 & 0 & 40 & 33 & & 27 & 7 & 5 & 0 & 27 & 5 & 0 & 14 & $28 \mid$ & 13 & 0 & & 0 \\
\hline $\begin{array}{l}\text { Health protection } \\
\text { (treatment) }\end{array}$ & 16 & 16 & 11 & 3 & 44 & 6 & 5 & 8 & 1 & 27 & 0 & 20 & 5 & 6 & 38 & 21 & 4 & 9 & 2 & 4 \\
\hline Politics & 18 & 24 & 10 & 0 & 34 & 13 & 5 & 8 & 4 & 15 & 22 & 39 & 5 & 0 & 44 & 17 & 6 & 7 & 3 & 0 \\
\hline $\begin{array}{l}\text { Enjoying life } \\
\text { (entertainment) }\end{array}$ & 17 & 14 & 6 & 7 & 29 & 14 & 6 & 10 & 4 & 8 & 2 & 37 & 0 & 2 & 49 & 23 & 12 & 9 & 1 & 2 \\
\hline Survival & 18 & 25 & 9 & 2 & 31 & 7 & 5 & 17 & 0 & 17 & 1 & 27 & 10 & 2 & 44 & 13 & 6 & 11 & 1 & 2 \\
\hline Religious life & 12 & 20 & 18 & 3 & 49 & 3 & 5 & 7 & & 31 & 2 & 17 & 6 & 24 & 33 & 14 & 4 & 7 & 1 & 4 \\
\hline Travel & 25 & 13 & 6 & 1 & 37 & 10 & 5 & 7 & 1 & 21 & 2 & 21 & 3 & 1 & 68 & 23 & 7 & 17 & & 0 \\
\hline Physical activity, sports & 16 & 13 & 12 & 6 & 30 & 18 & 4 & 8 & 2 & 12 & 0 & 21 & 1 & 2 & 57 & 23 & 16 & 11 & 1 & 3 \\
\hline $\begin{array}{l}\text { Buying/building } \\
\text { a house/flat }\end{array}$ & 19 & 17 & 23 & 11 & 29 & 5 & 5 & 16 & 0 & 3 & 8 & 23 & 0 & 0 & 61 & 23 & 9 & 6 & 0 & 2 \\
\hline $\begin{array}{l}\text { Renovating/decorating } \\
\text { a house/flat }\end{array}$ & 18 & 22 & 6 & 2 & 52 & 11 & 4 & 9 & 2 & 18 & 1 & 26 & 0 & 2 & 49 & 27 & 7 & 10 & 0 & 1 \\
\hline TOTAL & 15 & 19 & 10 & 4 & 39 & 10 & 4 & 8 & 2 & 15 & 1 & 21 & 2 & 4 & 43 & 17 & 8 & 9 & 2 & 5 \\
\hline
\end{tabular}

Yellow - areas to which the respondents devote themselves to a greater degree than others and would like to do that even more

Green - areas to which the respondents would like to devote themselves more than presently, to a greater degree than others

Source: CBOS (2019, p. 5). 
The Poles also devote their time to voluntary work in charity organisations - most often those helping children (indicated by 11 per cent of the respondents), but also those helping adults, including the ill, the disabled, the elderly, the poor, and the homeless (9.6 per cent). Every tenth respondent (10.3 per cent) works actively for the benefit of a parents' committee, a parents' council, a school or university foundation or another organisation operating in the area of schooling and education. Other - more or less formalised - citizens' groups and organisations in which Polish people are active, according to their declarations, include: religious and church movements and parish communities, sports clubs and associations, associations of garden plot holders, breeders, fishermen or hunters, the Voluntary Fire Service, the Voluntary Mountain Rescue Service, and other social rescue institutions, scout organisations, students' associations and other youth organisations, and slightly more rarely - also self-help organisations, artistic organisations, such as choirs, orchestras, and dance or theatre groups, animal care societies, seniors' and old age pensioners' clubs, district and housing estate self-governments, organisations supporting health care centres, country housewives' clubs and other women's organisations, and environment protection organisations (CBOS, 2018).

\section{Organisational benefits resulting from out-of-work activities of employees}

The conscious role of the work environment in balancing the work and out-of-work activity of employees certainly corresponds to the idea of sustainable development and the concept of corporate social responsibility, which can refer not only to the environment, economy, and society, but also to the life balance of an individual. In order to function effectively in work and private life, it is crucial to maintain a balance between the energy expended and the energy recovered. A healthy enterprise following the concept of sustainable development is one in which an employee can count on their needs being understood and on being enabled to pursue their outof-work hobbies, in which stress is relieved and healthy behaviours are promoted, including maintaining work-life balance.

At present, businesses need their employees to be creative and innovative, e.g. to be able to distinguish themselves and successfully compete in the modern dynamic and constantly changing business environment. If employees have no time for their hobbies, companies can pay a high price for that state of affairs. The ability to pursue hobbies can contribute to employees fulfilling their duties much better, e.g. by developing some key skills thanks to their hobbies. A creative hobby helps open one's mind to many different perspectives, which can be very useful in work life. 
Research findings indicate clearly that creative out-of-work activity may be a leisure activity that provides employees with the necessary resources to perform at a high level (DiNardi, 2019). Organisations that provide the most talented persons with personalised development plans and enable them to pursue their out-of-work interests, as well as build a supportive and integrating culture, derive greater benefits from their creativity. Although frequently some initial costs are involved, failure to take such steps may have serious consequences - the loss of those most talented resources. If organisations seek to create innovative solutions, they should promote cognitive diversity among their employees. Employees making up cognitively diverse teams can perceive problems differently and thus come up with better ideas and solutions.

Combining work and out-of-work interests makes it possible to make better use of an individual's potential and to acquire a broader range of competences and new experience. Individuals deriving inspirations, ideas, and trends from various sources are often able to offer their employers a fresh view and out-of-the-box ideas going beyond a single discipline. For this reason, spending too much time at work can cause an employee to be less patient due to the lack of time for their out-of-work activities. The frustration and resentment involved in this type of situation can be transplanted back to work. Balance is crucially important not only to the accomplishment of life objectives, but also work objectives, as an employee brings to their workplace the same positive or negative attitudes that they cultivate in their out-of-work activity.

Enabling employees to pursue their interests and hobbies can also contribute to their general intellectual development, which can significantly improve their wellbeing and thus cause them to be more energetic and fulfil their work duties with more optimism. Consequently, a happy employee functions better at work and is more creative, more focused, and able to cooperate better. They also find it easier to achieve an integrated self, by building a coherent image of themselves both at work and outside work. The positive emotions of an employee are also related to a reduced tendency towards unhealthy behaviours, less frequent hospitalisation and fewer absences from work. An employee's well-being requires emotional diversity, an authentic life, complex and rich in diverse experiences. Most certainly, an employee that has time for their private life and their interests and hobbies is more effective in performing their daily tasks at work.

\section{Conclusion}

The most important conclusions and the usefulness of the argumentation presented above are related to the thesis that sustainable development of human capital cannot be analysed without taking into consideration the out-of-work sphere, 
which constitutes an essential element of human life. At present, functioning in the dynamic and very changeable reality causes more and more persons to experience a conflict between work and private life, which results in disruptions to development. An individual will only be able to improve and develop, both in the general and the work dimension, in conditions enabling the complementarity of these two areas, to the benefit of both the employee and the employer.

A full analysis of interactions between work and personal life must take into consideration the issue of the mutual enrichment of work and private life. The real promotion of work-life balance in an organisation takes place when the employee feels that they are living a full, authentic life, and when they are able to be themselves and take responsibility for themselves both at work and outside work.

\section{References}

Bliese, P.D., \& Halverson R.R. (1996). Individual and nomothetic models of job stress: An examination of workhours, cohesion, and well-being. Journal of Applied Social Psychology, 26(13), 1171-1189.

Buell, P., \& Breslow, L. (1960). Mortality from CHD in Californian men who work long hours. Journal of Chronic Disease, 11(6), 615-626.

CBOS (2018). Komunikat z badań nr 29/2018, Aktywność Polaków w organizacjach obywatelskich. Retrieved from: https://www.cbos.pl/SPISKOM.POL/2018/K_029_18. PDF (accessed: 1.9.2019).

CBOS (2019). Komunikat z badań nr 3/2019, Czego życzyć Polakom w 2019? Retrieved from: https://www.cbos.pl/SPISKOM.POL/2019/K_003_19. PDF (accessed: 2.10.2019).

Chan, X.W., Kalliath, T., Brough, P., Oi-Ling S., O’Driscoll, M.P., \& Timms, C. (2016). Work-family enrichment and satisfaction: the mediating role of self-efficacy and work-life balance. The International Journal of Human Resource Management. 27(15), 1755-1776.

Clutterbuck, D. (2005). Równowaga między życiem zawodowym a osobistym: przewodnik dla specjalistów do spraw personalnych. Kraków: Oficyna Ekonomiczna.

DiNardi, G. (2019). Why You Should Work Less and Spend More Time on Hobbies. Harvard Business Review. Retrieved from: https://hbr.org/2019/02/why-you-shouldwork-less-and-spend-more-time-on-hobbies (accessed: 19.10.2019).

Flash Eurobarometer 470(2018). Work-Life Balance, European Union. Retrieved from: http:// data.europa.eu/euodp/en/data/dataset/S2185_470_ENG (accessed: 16.10.2019).

Galambos, N.L., \& Walters, B.J. (1992). Workhours, schedule in flexibility and stress in dual-earner spouses. Canadian Journal of Behavioural Science, 24(3), 290-302.

Gotowska, M. (2014). Work Life Balance w modelu równowagi życia (bytu). In: R. Tomaszewska-Lipiec (Ed.), Relacje praca-życie pozazawodowe drogą do zrównoważonego rozwoju. Bydgoszcz: Wydawnictwo Uniwersytetu Kazimierza Wielkiego. 
Greenhaus, J.H., \& Powell, G.H. (2006). When work and family are allies: A theory of work-family enrichment. Academy of Management Review, 31(4), 72-92.

GUS (2019). Rynek pracy w 2017 r. Retrived from: https://stat.gov.pl/obszary-tematyczne/rynek-pracy/zasady-metodyczne-rocznik-pracy/rynek-pracy-w-2017-r-,4,1. html (accessed: 11.10.2019).

Henion, A., \& Ryan, A.M. (2013). Wanted: A life outside the workplace. Retrieved from: http://msutoday.msu.edu/news/2013/wanted-a-life-outside-the-workplace/ (accessed: 14.10.2019).

HRK (2016). Raport z badania: Work-life balance. Niewykorzystany potencjał. Retrieved from: www.wlb-hrk.pl (accessed: 30.9.2019).

Maulik, P.K. (2017). Workplace stress: A neglected aspect of mental health wellbeing. The Indian Journal of Medical Research, 146(4), 441-444.

Netemeyer, R.G., Brashear-Alejandro, T., \& Boles, J.S. (2004). A cross-national model of job-related outcomes of work role and family role variables: A retail sales context. Journal of the Academy of Marketing Science, 32(1), 49-60.

OECD (2019). Average annual hours actually worked per worker. Retrieved from: https:// stats.oecd.org/Index.aspx?QueryId=10162 (accessed: 9.10.2019).

Sparks, K., Cooper, C., Fried, Y., \& Shirom, A. (1997). The effects of hours of work on health: A meta-analytic review. Journal of Occupational and Organizational Psychology, 70(4), 391-408.

Stankiewicz-Mróz, A. (2008). Zmiany w obszarze funkcji personalnej wynikającej z implementacji koncepcji „work-life balance”. In: E. Jędrych, A. Pietras, A. Stankiewicz-Mróz (Eds.), Funkcja personalna w zmieniajacej się organizacji. Łódź: Wydawnictwo Media Press, 314-322.

Tomaszewska, R. (2016). Równoważenie sfery osobistej i zawodowej jako postulowany element nowoczesnego środowiska pracy. Szkoła-Zawód-Praca, 12, 92-115.

Tucker, P., \& Rutherford, C. (2005). Moderators of the relationship between long workhours and health. Journal of Occupational Health Psychology, 10 (4), 465-476.

WHO (2017). Depression and Other Common Mental Disorders: Global Health Estimates. Geneva, World Health Organization. Retrieved from: ttps://apps.who.int/iris/ bitstream/handle/10665/254610/WHO-MSD-MER-2017.2-eng.pdf?sequence=1 (accessed: 12.10.2019).

Work Service Report (2017). Barometr Rynku Pracy VIII, Warszawa. Retrieved from: http://www.workservice.com/pl/Centrum-prasowe/Raporty/Barometr-Rynku-Pracy/Barometr-Rynku-Pracy-Work-Service-VIII-edycja (accessed 14.10.2019).

Work Service Report (2019). Barometr Rynku Pracy XII, Warszawa. Retrieved from: http://www.workservice.com/pl/Centrum-prasowe/Raporty/Barometr-Rynku-Pracy/Barometr-Rynku-Pracy-Work-Service-XII-edycja (accessed 14.10.2019). 


\section{Katarzyna Mikołajczyk}

$\mathrm{PhD}$ in humanities in the field of andragogy. She is a graduate of the Pedagogical Faculty of the University of Warsaw and Postgraduate Group Trainer Studies at the SWPS University of Social Sciences and Humanities. She is an Assistant Professor at the Institute of Human Capital at SGH Warsaw School of Economics. Her research interests focus on human capital in the organisation: training, employee development and well-being, digitisation in development processes, modern methods and tools for employee development, communication and relationships in teams.

e-mail address: katarzyna.mikolajczyk@sgh.waw.pl

ORCID: 0000-0003-0630-4382 